\title{
EXCHANGE OF RESPIRATORY GASES IN CHRONIC URAEMIA AND ANAEMIA, IN RELATION TO ANAESTHESIA
}

\author{
P.R. Ramachandran, M.B., B.S., F.R.C.P.(c) and A.F.D. Cole, M.D., F.R.C.P.(c)
}

AMONG THE PROBLEMs presented by the chronic uraemic patient, the anaesthetist is particularly concerned with anaemia, ${ }^{1-3}$ acid-base and electrolyte upsets, and impaired renal excretion of drugs. When such patients are on chronic haemodialysis programs, they frequently present for surgical creation or revision of arteriovenous shunts and fistulae. Usually, these procedures are done under local or regional anaesthesia, but for some general anaesthesia may be indicated because of temperamental unsuitability to, or outright refusal of, local anaesthesia.

The standard method of laboratory assessment of respiratory gas exchange is the determination of partial pressures of carbon dioxide and oxygen in arterial blood. However, in anaemia, with the associated decrease in oxygen content of blood, arterial blood gas tensions, indicating the effectiveness of gas exchange between pulmonary blood and alveolar air, do not offer all the desired information, especially concerning tissue gas exchanges.

Events occurring at the tissue/blood gas exchange area must be at least as important to the organism as those in the air/blood exchange area. Since direct measurement of tissue gas tensions is not generally feasible, other indicators must be sought. End-capillary blood gas tensions reflect the tensions in the tissue with which that blood has equilibrated. ${ }^{4}$ Therefore, postulating that central venous blood gas tensions might be a valuable indicator of tissue gas tensions (since. central venous blood is in effect pooled end-capillary blood, albeit not perfectly mixed) we studied arterial and central venous blood gas and hydrogen ion status in five chronic uraemic patients receiving general anaesthesia for arterio-venous shunt or fistula. Their ages ranged from 20 to 52 years. All were anaemic (haemoglobin 4.5 to $6.8 \mathrm{gm} \%$ ) and azotaemic (BUN 42 to $65 \mathrm{mgm} \%$ ). In some, electrolyte abnormalities of mild to moderate degree were present. These data are itemized in Table I.

TABLE I

\begin{tabular}{|c|c|c|c|c|c|c|}
\hline \multirow[b]{2}{*}{ No. } & \multirow[b]{2}{*}{ Age } & \multirow{2}{*}{$\begin{array}{l}\mathrm{Hb} \text {. } \\
\text { Gms. }\end{array}$} & \multicolumn{3}{|c|}{ ELECTROLYTES $\mathrm{mEq} / \mathrm{L}$} & \multirow{2}{*}{$\begin{array}{l}\text { Days from } \\
\text { Dialysis. }\end{array}$} \\
\hline & & & $\mathrm{Na}$ & $\mathbf{K}$ & $\mathrm{Cl}$ & \\
\hline 1. & 52 & 5.0 & 127 & 4.1 & 89 & 1 \\
\hline 2. & 47 & 6.3 & 136 & 4.4 & 91 & 2 \\
\hline 3. & 20 & 4.9 & 135 & 6.0 & 88 & 3 \\
\hline 4. & 44 & 6.8 & 144 & 5.8 & 94 & 2 \\
\hline 5. & 31 & 4.5 & 138 & 5.3 & 95 & 3 \\
\hline
\end{tabular}

Read at the Annual Meeting of the Canadian Anaesthetists' Society in Halifax, June, 1972. 736

Canad. Anaesth. Soc. J., vol. 20, no. 6, November 1973 


\section{METHOD}

One hour before surgery, patients were premedicated with 25 to $75 \mathrm{mgm}$ meperidine subcutaneously. Prior to induction of anaesthesia, atropine 0.3 to 0.6 mgm with d-tubocurarine $4 \mathrm{mgm}$ was given intravenously. For five minutes prior to induction, 100 per cent oxygen was administered by face mask. Anaesthesia was induced with a minimum sleep dose of thiopentone (100-175 mgm). After $80 \mathrm{mgm}$ of succinylcholine intravenously the larynx was sprayed with topical lidocaine, $40 \mathrm{mgm}$, and the trachea was intubated. Anaesthesia was maintained with nitrous oxide $6 \mathrm{~L} / \mathrm{min}$, oxygen $4 \mathrm{~L} / \mathrm{min}$ and methoxyflurane 0 to 0.7 per cent by Magill circuit with spontaneous ventilation.

Five per cent dextrose in water was infused during the operation at a rate of 100 to $150 \mathrm{ml}$ per hour. At the end of the operation anaesthesia was discontinued and the patients were removed to the recovery room, where they received oxygen by nasal catheter at a flow of $5 \mathrm{~L} / \mathrm{min}$ for one hour.

Clinical monitoring with pulse rate, brachial arterial pressure (Riva-Rocci method) lead II electrocardiogram, central venous pressure, and respiratory rate and depth (assessed subjectively) revealed no significant disturbance of these cardio-respiratory parameters, either during the anaesthetic or in the post-anaesthetic period.

Central venous blood was drawn from a catheter inserted percutaneously through the external jugular or median basilic vein into the superior vena cava. Location of the catheter tip was determined radiologically. Arterial blood was drawn from the radial or the femoral artery. Arterial and central venous samples were drawn simultaneously as follows: (I) before premedication, (2) one hour after induction of anaesthesia, and (3) 90 minutes after discontinuing anaesthesia (i.e. 30 minutes after discontinuing nasal oxygen in the recovery room).

Blood was collected anaerobically in heparinized glass syringes and analysed immediately for $\mathrm{pH}, \mathrm{P}_{\mathrm{CO}_{2}}$ and $\mathrm{P}_{\mathrm{O}_{2}}$ at $37^{\circ} \mathrm{C}$ using an IL $\mathrm{pH}$ gas analyzer.

\section{Results}

The blood gas and $\mathrm{pH}$ data are presented in Tables II, III and IV. As one would expect, the arterial and central venous oxygen tension values increased during anaesthesia (when FIO. was 0.4 ) and returned to the pre-anaesthetic levels after anaesthesia.

In most cases arterial carbon-dioxide values increased during anaesthesia by up to $5 \mathrm{~mm} \mathrm{Hg}$, to return to the pre-anaesthetic levels after anaesthesia.

The $\mathrm{pH}$ values followed the changes in $\mathrm{P}_{\mathrm{CO}_{2}}$.

\section{Discussion}

Our chief concern in these patients was the reduced oxygen-carrying capacity of their blood because of severe chronic anaemia. ${ }^{5}$ It is generally accepted that in these patients in most situations, the risks of transfusion outweigh the benefits, unless the anaemia is severe enough to cause symptoms such as shortness of 
TABLE II

Changes in Oxygen Tension

\begin{tabular}{|c|c|c|c|c|c|c|}
\hline & \multicolumn{2}{|c|}{ Pre-op. } & \multicolumn{2}{|c|}{ Per-op. } & \multicolumn{2}{|c|}{ Post-op. } \\
\hline & a & $\mathrm{cv}$ & $\mathrm{a}$ & $\mathrm{cv}$ & a & $\mathrm{cv}$ \\
\hline $\begin{array}{l}1 . \\
2 . \\
3 . \\
4 . \\
5 .\end{array}$ & $\begin{array}{l}69.0 \\
77.0 \\
62.0 \\
60.0 \\
90.0\end{array}$ & $\begin{array}{l}20.0 \\
30.0 \\
32.0 \\
26.0 \\
35.0\end{array}$ & $\begin{array}{r}158.0 \\
90.0 \\
89.0 \\
136.0 \\
120.0\end{array}$ & $\begin{array}{l}25.0 \\
30.0 \\
33.0 \\
34.0 \\
40.0\end{array}$ & $\begin{array}{l}65.0 \\
78.0 \\
73.0 \\
61.0 \\
76.0\end{array}$ & $\begin{array}{l}22.0 \\
20.0 \\
35.0 \\
30.0 \\
39.0\end{array}$ \\
\hline $\begin{array}{l}\text { Mean } \\
\text { S.D. }\end{array}$ & $\begin{array}{l}71.6 \\
10.97\end{array}$ & $\begin{array}{r}28.60 \\
5.20\end{array}$ & $\begin{array}{r}118.60 \\
26.65\end{array}$ & $\begin{array}{r}32.40 \\
4.92\end{array}$ & $\begin{array}{r}70.60 \\
6.53\end{array}$ & $\begin{array}{r}28.80 \\
6.79\end{array}$ \\
\hline
\end{tabular}

$\mathrm{a}=$ arterial.

$\mathrm{cv}=$ central venous.

TABLE III

Changes in $\mathbf{p H}$

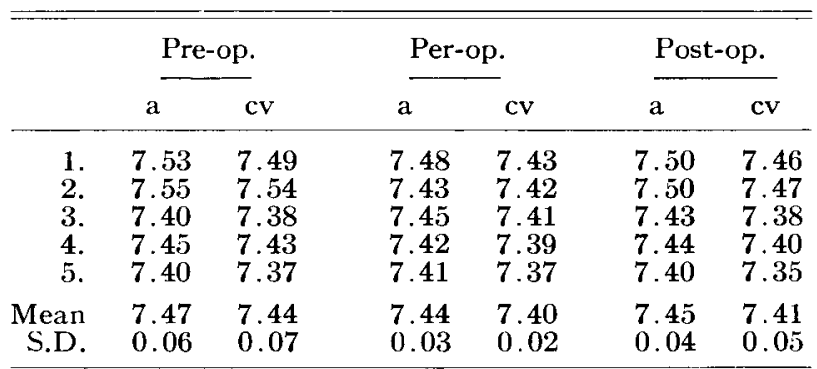

$\mathrm{a}=$ arterial.

$\mathrm{cv}=$ central venous.

TABLE IV

Changes in Carbon-Di-Oxide Tension

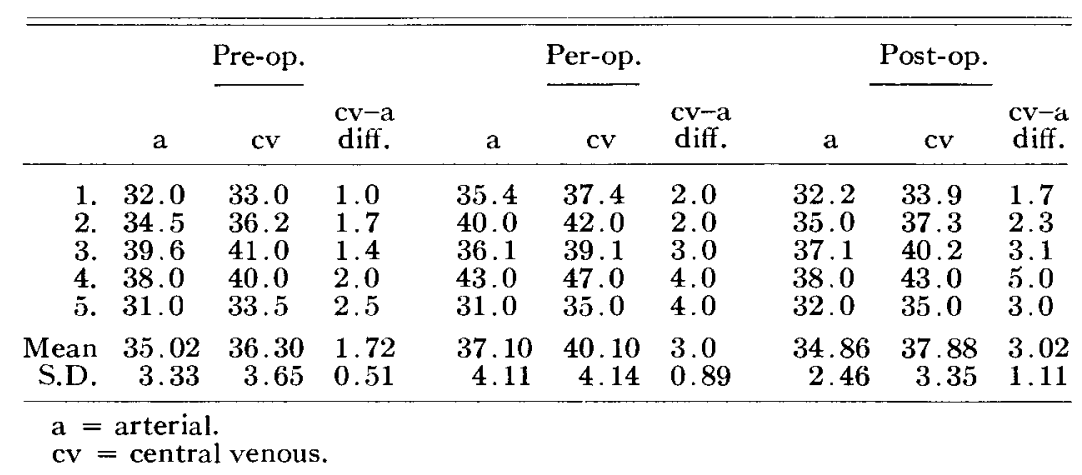

breath and syncope. ${ }^{3}$ However, the applicability of this policy to the patient receiving general anaesthesia is questionable, because of the increased risks of potential hypoxia in a patient with reduced oxygen reserves. ${ }^{5}$

The increases in arterial and central venous oxygen tensions observed in our patients during anaesthesia with a raised inspired oxygen, imply that the anaesthetic technique did not jeopardize blood or tissue oxygenation either during or 
after the anaesthetic. In fact, the available indices of tissue oxygenation indicated an improvement rather than any detrimental effect, during general anaesthesia administered with scrupulous attention to anaesthetic technique.

The rise in central venous oxygen tension in all patients during anaesthesia might reflect the increase in arterial oxygen content due to increased inspired oxygen tension, with more oxygen "left over" in venous blood after the tissues have extracted their requirements, or a decrease in tissue oxygen consumption. The possibilities of increased cardiac output or redistribution of cardiac output away from metabolically active organs do exist, but seem unlikely.

Bendixen and Laver pointed out that oxygen stores, for the most part, lie in the arterial blood oxygen content. ${ }^{5}$ It is easy when considering the anaemic patient, to imagine a situation where, in certain tissues, not only are the oxygen reserves reduced, but they may be exhausted. As the blood flows through the capillaries of such tissues the blood oxygen tension may drop below the "critical capillary $\mathrm{P}_{\mathrm{O}_{2}} " 4$ and the oxygen supply may fail to meet the demand. That is, in the latter part of its capillary course, the blood oxygen tension would be so low that regardless of how hypoxic the tissue, an insufficient tension gradient would exist to maintain oxygen diffusion.

In such a tissue, when oxygen supply is marginal, a small elevation of arterial oxygen content would permit diffusion of oxygen into tissues over a greater part of the course of the capillary, but would not alter end-capillary $\mathrm{P}_{\mathrm{O}_{2}}$ until such time as the critical capillary $P_{0.2}$ was avoided even when the blood reached the venous end of the capillary. Such a chain of events might be reflected in a smaller-than-expected rise in central venous oxygen content and tension in the severely hypoxic patient who is allowed to breathe an oxygen-enriched mixture.

While this study provides insufficient data to assess this possibility, it may be interesting to note Case 1 , Table II. This patient's central venous $\mathrm{P}_{\mathrm{O}_{2}}$ remained below $30 \mathrm{~mm} \mathrm{Hg}$ even when her arterial $\mathrm{P}_{\mathrm{O}_{2}}$ increased from $65 \mathrm{~mm} \mathrm{Hg}$ to 158 $\mathrm{mm} \mathrm{Hg}$ during anaesthesia $\left(\mathrm{F}_{\mathrm{O}_{2}} \mathbf{0 . 4}\right)$, and she died in the post-operative period.

The normal central venous oxygen tension is $35 \mathrm{~mm} \mathrm{Hg}$ or more, ${ }^{6,7}$ and it has been suggested that a central venous oxygen tension less than 30 indicates tissue hypoxia. ${ }^{8}$ Our findings support this, and suggest that a central venous oxygen tension below 30 indicates the urgent need for appropriate therapeutic measures, e.g. raising inspired oxygen concentration, and/or blood transfusion.

The arterial carbon dioxide tensions indicating hyperventilation in the preoperative and post-operative periods are unexplained. Possible explanations include fear, pain, cerebral irritation from uraemia, tissue (especially central nervous system) hypoxia, or other central nervous system abnormalities such as localized acidosis. Examination of the data shows that the hyperventilation is not a compensation for systemic metabolic acidosis as, in fact, these patients consistently had metabolic alkalosis, which was purposely induced during their dialysis.

Relatively little significance has been attached to central venous carbon dioxide tension. Examination of blood from the right atrium in normal man, ${ }^{9}$ and from the central venous pool in patients in respiratory failure ${ }^{6}$ have demonstrated that, on the average, central venous carbon dioxide tension is higher than arterial by 
5 to $6 \mathrm{~mm} \mathrm{Hg}$. In this study, it was noted that the arterial to central venous difference in $\mathrm{CO}_{2}$ tension ranged from 1 to $2.5 \mathrm{~mm} \mathrm{Hg}$ before premedication, from 2 to $4 \mathrm{~mm} \mathrm{Hg}$ during anaesthesia and surgery, and from 1.7 to $5 \mathrm{~mm} \mathrm{Hg}$ postoperatively. Most of these values are well below the mean normal of 5 to $6 \mathrm{~mm} \mathrm{Hg}$. While we cannot be dogmatic, we do suggest that the reason for this is as follows:

If one were to use $\mathrm{CO}_{2}$ as the indicator, the Fick equation for cardiac output would be written:

cardiac output $=\mathrm{K} . \mathrm{VCO}_{2} /(\mathrm{V}-\mathrm{A})\left[\mathrm{CCO}_{2}\right]$

The carbon dioxide dissociation curve is linear in the range of 30 to $50 \mathrm{~mm}$ $\mathrm{Hg}$, i.e., carbon dioxide tension is directly proportional to content. Since haemoglobin levels are low in these patients, carbamino haemoglobin levels are also low. Therefore the shift in the carbon dioxide dissociation curve with oxygenation and reduction of haemoglobin (Haldane effect) ${ }^{10}$ will be small in these patients.

Therefore, we can substitute tension for content in the equation,

cardiac output $=\mathrm{K}_{2} \mathrm{VCO}_{2} / \mathrm{P}_{2} \mathrm{CO}_{2}-\mathrm{PaCO}_{2}$

In other words, with a constant $\mathrm{CO}$. production, cardiac output is inversely proportional to the central veno-arterial $\mathrm{CO}_{2}$ tension difference. In our patients, a high cardiac output would result in the low $\mathrm{CO}_{2}$ tension difference observed.

Nunn has suggested that the arterial-to-tissue difference in $\mathrm{CO}_{2}$ tension is a function of tissue blood flow. ${ }^{10}$ If venous carbon dioxide tensions represent the tissues they drain, then a low central venous-arterial carbon dioxide tension difference, pursuing the analogy, would suggest a high perfusion rate (cardiac output).

It is generally considered that compensatory mechanisms for anaemia include (a) increased tissue perfusion (i.e. cardiac output) $)^{5,11,14}$ and (b) increased oxygen extraction from arterial blood, both by lowering tissue (and end-capillary) oxygen tensions, ${ }^{5}$ and by altering the affinity of haemoglobin for oxygen. ${ }^{12,13}$ The low central venous to arterial carbon dioxide tension differences suggest high cardiac outputs, which are in keeping with observations in chronic renal failure, ${ }^{\mathbf{1 4}}$ and the low central venous oxygen tensions suggest low tissue oxygen tensions.

Our experience lends weight to the contention that measurement of central venous blood gases as well as arterial blood gases, provides clinically significant information in the management of the patient at risk of tissue hypoxia.

\section{SUMMARY}

Arterial and central venous blood-gas and hydrogen ion status were studied in relation to anaesthesia in five patients with chronic uraemia and associated anaemia. Low central venous oxygen tension values were observed in all these patients, indicating increased oxygen extraction by the tissues. Low central venous to arterial differences in carbon-dioxide tensions were common in these patients, suggesting a high cardiac output.

The effect of anaesthesia on the blood gas and hydrogen ion status in these patients, and the clinical significance of the changes are discussed. 


\section{RÉSUMÉ}

Les gaz artériels et les gaz veineux centraux ainsi que la teneur en ion $\mathbf{H}^{+}$ furent étudiés en relation avec l'anesthésie chez cinq malades atteints d'urémie chronique associée de l'anémie.

Chez tous ces malades en observa une tension veineuse centrale basse en $\mathrm{O}_{2}$ indiquant une utilisation accrue en $\mathrm{O}_{2}$ par les tissus.

Chez ces malades, on trouvait habituellement une faible différence entre la tension en $\mathrm{CO}_{2}$ artérielle et veineuse centrale, suggérant ainsi un débit cardiaque élevé.

L'effet de l'anesthésie sur les gaz sanguins ainsi que sur la teneur en ion $\mathrm{H}^{+}$de ces malades, de même que la signification clinique de ces changements sont discutés.

\section{REFERENCES}

1. Merruld, J.P. The treatment of renal failure, 2nd edition, New York and London: Grune \& Stratton (1966).

2. Hamburger, J., Richet, G., Crosnier, J., Funck-Bretano, J.L., Antoine, B., Ducrot, H., Merz, J.P., \& De Montera, H. Nephrology, Vol. 1 and 2, W.B. Saunders (1968).

3. Strauss, M.B. \& Welt, L.G. Diseases of the kidney, 2nd Edition, Little, Brown \& Co. (1971).

4. Finch, C.A. \& L'Enfant, C. Oxygen transport in man. New Eng. J. Med. 286: 8, 407415 (1972).

5. Bendixen, H.H. \& Laver, M.B. Hypoxia in anaesthesia. A review. Clin. Pharm. \& Therapeutics 6: $510-539(1665)$.

6. Ramachandran, P.R., Fairlex, H.B., \& Laws, A.K. Central venous blood as an index of acid-base and oxygenation. Can. Anaes. Soc. J. 15: 4, 332-346 (1968).

7. SuUtarinen, T. \& Mattila, M.A.K. The importance of central venous blood in clinical practice. Acta Anaesth. Scand. Suppl. XXXVII: 106-111 (1970).

8. Gustafson, J. \& Nordstrom, L. Central venous $\mathrm{PO}_{2}$ and open heart surgery. Acta Anesth. Scand. Suppl. XXXVII: 112-113 (1970).

9. Cournand, A., Riley, R.L., Breed, E.S., Baldwin, E. de F., \& Richards, D.W., Jr. Measurement of cardiac output in man using technique of catheterization of the right auricle or ventricle. J. Clin. Invest. 24: 106-116 (1945).

10. NunN, J.F. Applied respiratory physiology. Butterworth, Long (1969).

11. Roy, S.B., Bhatia, M.L., Mather, V.S., \& Virmani. Hemodynamic effects of chronic severe anemia. Circulation 28: 346-356 (1963).

12. KenNedY, A.C. \& VAltis, D.J. Oxygen dissociation curve in anemia of various types. J. Clin. Invest. 33: 1172-1382 (1954).

13. Torrance, J., Jacobs, P., Restrepo, A., Eschbach, J., L’Enfant, C., \& Finch, C.A. Intra-erythrocytic adaptation to anemia. New Eng. J. Med. 283: 4, 165-169 (1970).

14. Mostert, J.W., Evers, J.L., Habika, G.H., Moore, R.H., Kenny, G.M., \& Murphy, G.P. The haemodynamic response to chronic renal failure as studied in azotaemic state. Brit. J. Anaesth. 42: 397-411 (1970). 